\title{
Hamlet: The Dialectic Between Eye and Ear
}

\section{MARY ANDERSON}

W hat do we know about Hamlet? He is young, educated, sensitive, and in a dilemma. We know that the practical issue of truth and judgement preoccupies him. He is a university student at Wittenberg and has a "studious temperament", illustrated by the fact that he is eager to get back to school. ${ }^{1,2}$ He debates and deliberates at great length and gives the appearance of one who is oriented toward word rather than action. We can assume that Shakespeare's characterization of Hamlet as an intellectual carries some philosophical and thematic import, and that the play is, at least in part, about the difficulty of achieving certainty, truth, and meaning, as a basis for action in the world. There is a "general air of uncertainty" in the play and, as A. Brennan points out, "Truth is so elusive that you can only sneak up on it to catch it by surprise". 3,4

In Hamlet, both the play and the character, Shakespeare provides a series of images which examine the various ways of gaining knowledge and certainty as a basis for judgement and action. ${ }^{5}$ He sets up a comparison between the eye and the ear as the two faculties by which sense data are transmitted to the reason. The frequent and deliberate repetition of these images in the play invites analysis and provides a comprehensive structure by which the play can be better understood.

In Hamlet the importance of reason is emphasized, and this faculty is elevated to "noble", "sovereign", "ingenious", and "godlike" status (III.i.157; V.i.248; IV.iv.39). The function of language is implicit in the relationship between the eye and the ear, and the power of the word for good or evil is a central theme in the play.

As well as the eye and ear, the images dealing with one or more of the five senses are especially important to characterization. The five senses represent an image of completeness, and when one or more is absent, this denotes a deficiency. The repetition of certain words or phrases according to the number 
five and its multiples, suggests purpose and design in which theme and structure coalesce into meaning.

The Revenge Code is also a major theme in the play and we observe Hamlet being torn between his desire to fulfill his father's wish for revenge, and his knowledge that the act is unlawful and immoral. When we consider the grave moral and philosophical paradoxes that the ghost of Hamlet's father presents, is it any wonder that Hamlet is uncertain how to act ${ }^{6}$ Brecht sees Hamlet as "historically between two worlds, unhappy with the dark revenge duty, yet unable to find another way to act. ... In the bloody business of feudal revenge reason merely impedes him". ${ }^{7}$

Much has been written about the Revenge Code in Hamlet. Fredson Bowers outlines the historical development of the prohibition against revenge in Elizabethan England, and its severe and legal punishment as murder. ${ }^{8}$ Also, as Harbage notes, had Hamlet taken revenge, he would have become a villain. ${ }^{9}$ In fact Shakespeare's most violent play, Titus Andronicus (1594) written about six years before Hamlet, dramatizes the chain of bloodshed that can be set in motion by the act of revenge. Hamlet's struggle with the revenge duty is contrasted in the play with the character of Fortinbras who also seeks to revenge his father's death; with Laertes, who rejects "words" and would cut Hamlet's "throat i' th' Church"; and with Claudius, who tells Laertes, "Revenge should have no bounds" (IV.vii.126-28).

The role of the theatre as a medium which incorporates both the eye and the ear in the transmission of ideas is also a central theme in the play. Therefore, Shakespeare in the play Hamlet, and like his character Hamlet, devises a play which will project his ideas and pique the political and social conscience. In this play Shakespeare demonstrates his views about the moral function of the theatre in its capacity to stimulate a more balanced understanding in its audience. Wilson suggests that in Hamlet a kind of dramatic dialectic was being imposed upon the Elizabethan audience. He states:

And the audience, of whatever school, would be swayed hither and thither in their opinion, as Hamlet himself was swayed. ${ }^{10}$

Thus the strongly held views and biases would become moderated and tempered by an opposing viewpoint.

Hamlet as a scholar, places greater emphasis on the intellect and on reason and the word. He says that he is "sicklied o'er with the pale cast of thought", and that he "must like a whore, unpack [his] heart with words" (III.i.84; II.ii.585). Hamlet obviously struggles with the onerous burden of freedom of 
choice, while at the same time feeling the equal burden of fate - the inherent "mole" or "defect", by which each individual in the play is undone (I.iv.2438). He is caught between the past and the future - the biblical "sins of the fathers", and the freedom of self-determination.

The importance of the images of the eye and ear is not restricted to Hamlet alone and reference to them can be found in some of the other plays. Notably, in Henry $V$ the King judges as admirable the man who is "Not working with the eye without the ear" (H5.II.ii.135,6). Also Allan Bloom points out that in Julius Caesar:

Caesar had bad hearing but good eyes; Cassius, bad eyesight and good hearing. Caesar trusted more to what he saw than what he heard; Cassius trusted the report he heard about what another saw. ${ }^{11}$

In each case the suggestion is made that a reliance on one faculty without the balance of the complementary other will result in unwholesome judgement and action.

In the first act of Hamlet alone there are at least one hundred references to the eye and the ear and their functions of seeing and hearing. In the second act there are eighty-four, and the repetitions continue throughout the play. In fact, the careful staging and juxtaposition of the Dumb-Show and Mouse-Trap sequence provides a dramatization of the functions of the eye and ear and of the relative effectiveness of the two forms of drama.

The following images and scenes are selected in order to demonstrate a deliberate juxtaposition of the eye and ear in a significant way: the images of malignancy associated with the ear; the actual murder of the King; the appearance of the ghost; the Dumb-Show and Mouse-trap sequence; the prayer scene; the killing of Polonius; Hamlet and the Queen; and Ophelia.

In particular there are many references to danger and violence connected with the ear. A few are quoted here and others will follow as they become relevant:

Nor shall you do my ear that violence (I.ii.171).

Too credent ear (I.iii.31).

The whole ear of Denmark is rankly abused (I.v.36-7).

Takes prisoner Pyrrhus ear (II.ii.477).

Cleave the general ear with horrid speech (II.ii.562).

To spleet the ears (III.ii.10).

Mildewed ear (III.iv.64).

Knavish speech sleeps in a foolish ear (IV.ii.23).

To infect his ear with pestilent speeches (IV.v.90) 
I have words to speak in thy ear will make thee dumb (IV.vi.24,5).

It is interesting that Shakespeare uses a similar image in Macbeth when Lady Macbeth resolves to convince her husband that he should have the crown. She says, "Hie thee hither,/ That I may pour my spirits in thine ear" (Mac.I.v.25,6).

The play Hamlet, suggests that information gained through the ear alone can be malignant, and that information gained through the eye alone can be incomplete or ineffectual. Shakespeare shows that a dialectical relationship exists between the functions of the eye and the ear and that an equilibrium between the two must be sought within the reason before the will is called into action. This accounts for Hamlet's repeated deliberations and inability to act. He is not certain that his sources, or his senses, are reliable, and this is compounded by the fact that his major source is intangible.

It is significant that the play begins on a speculation about hearing and seeing. The appearance of the ghost has already occurred twice before the play opens. Line 1 states "Who's there?", and line 21 asks, "What, has this thing appear'd again to-night?". The ghost exercises a strong influence on the "sentinels" of the kingdom who have their eyes and ears open and alert, but it is only Hamlet, the ghost's natural issue, who can communicate with it. The ghost repeatedly engages his ear, "lend thy serious hearing", and "List, list, O, list". Hamlet replies "Speak, I am bound to hear" (I.v.5-7).

In the ghost's speech King Hamlet describes the circumstances of his murder. The words of the ghost are particularly significant since they also are concerned with hearing:

I find thee apt,

Now, Hamlet, hear:

... the whole ear of Denmark

Is by a forged process of my death

Rankly abused;. ... (I.v.32-38) (my emphasis).

It is important that the ghost makes this statement even before he mentions the poisoning in his own ear, and thereby sets up an analogy between the poisoning of the "whole ear" of the nation, and the poisoning of the ear of the King. The words "forged process" refer to the misuse of language and authority, by which the nation has been duped. In order to emphasize the function of hearing even more cogently, the ghost engages Hamlet's ear, by saying "Now, Hamlet, hear" (I.v.34). Ironically, it is by the same process that 
caused his own death, that the ghost appeals to Hamlet - directly through the ears. Hamlet must decide if this communication is also poisonous.

Hamlet, does also see the ghost, however intangibly, and it has been seen by others as well, but whether Hamlet can rely on his senses as a basis for judgement and action is his dilemma. He is confused because he has also seen his father in his "mind's eye" and in his "prophetic soul" (I.ii.186; I.v.40). Hamlet's "remembering" of his father and his subsequent thought patterns and inward struggle show that a dialectic is taking place (I.v.92-112).

One of the central images in the play is connected with the ear. It is the murder of the king and is particularly bizarre. He is poisoned by his brother who pours a "leprous distillment" into the "porches of [his] ears", while he is asleep (I.v.63) (my emphasis). We note the plural "ears". How does a murderer penetrate both ears without waking his victim? ${ }^{12}$ Does this then refer to the faculty of hearing, which is a natural and simultaneous penetration of both ears into the reason? This suggests that the poison is connected with language and that a knowledge gained through hearing alone without benefit of the tempering and moderating value of its complementary faculty, eyesight, can be corrupting to both mind and body.

In the ghost's speech to Hamlet, he mentions all five of the senses, but the fact that his eyes were closed made the murder possible. This implies a potential for sensual wholeness, but a rational deficiency is also suggested by the image of complacency in the "custom" of napping in the unprotected "orchard" (I.v.58-90).

After speaking with the ghost, Hamlet appears to be resolved to act, however, we find that he continues to be torn between his father's impassioned plea for justice based on the Revenge Code, and the Christian proscription against it. Hamlet's dilemma is complicated by the fact that the ghost himself is an image of contradiction. On the one hand, the ghost is already condemned to burn in hell for his past sins, and on the other, he would now add another sin, revenge, to the list. It is left to the young scholar Hamlet to attempt to find a way to justice and certainty that would accommodate both the past tradition and the present philosophy. This is a task worthy of a Socrates.

Immediately after the ghost's speech, Hamlet repeats the word "all" five times, and these are incorporated with ten references to actual written language. This demonstrates that a total change, a "resolution", has taken place in his "distracted globe", which is his reason. He says: 
Yea, from the table of memory

I'll wipe away all trivial fond records,

All saws of books, all forms, all pressures past

That youth and observation copied there,

And thy commandment all alone shall live

Within the book and volume of my brain

(I.v.98-103) (my emphasis).

At the end of this speech, Hamlet replaces "all" previous memory with a new "word" which he swears and writes down - "remember me". Ironically, in the very act of denying the various forms of language, he is compelled to employ the written word, and not merely to "remember", and so he demonstrates the power of the word over him. Thus the play shows Hamlet, in spite of himself, to be primarily language oriented rather than action oriented, and this scene suggests that his method of action will be by means of the word.

Immediately after the ghost scene Hamlet appears to be resolved to act by means of the sword, but again his resolution is blurred by language. After the ghost scene, there is a very curious play on the words "swear" and "sword" (I.v.143-81). Hamlet requires his "friends, scholars and soldiers" to "swear" on the concrete object of his "sword", and not on "faith" as they are inclined to do. In this scene, the words "swear" or "sworn" are repeated ten times and "sword" is repeated five times, so that a totality is alluded to. "Swear" is a language act, and "Sword" is a combination of "word" and an object of action. Together they represent the conjunction of language and action, or word and deed, which later becomes Hamlet's word-sword method of action.

However, at this point, and in spite of what appears to be resolution, Håmlet is still unable to act until he finds the proper method. The air of tension grows in the play, and Brennan points out that the audience builds up a "resistance to the desire to see a final face-to-face confrontation between Claudius and Hamlet", as is seen in the "two-dimensional heroes, who feature so frequently in revenge dramas". ${ }^{13}$ The audience hopes that Hamlet, the scholar, will be able to find a better way.

There is a curious metaphorical pun in the fact that it is only after speaking to the 'actors' that Hamlet is able to 'act'. Hamlet undergoes a change in character and comes to the realization that his weapon lies in language; that word and sword are the same weapon; and that theatre will be the effective medium. ${ }^{14} \mathrm{He}$ says that he will ... 
... cleave the general ear with horrid speech,

Make mad the guilty, and appall the free,

Confound the ignorant, and amaze indeed

The very faculties of eyes and ears.

[I] Must like a whore unpack my heart with words

The play's the thing

Wherein I'll catch the conscience of the King (II.ii.561-605).

This passage is packed with significance as we note the word-sword imagery in the phrase "cleave the general ear", and the reference to the profound effect of the "play" on the "faculties of eyes and ears". The images evoked by the words "mad", "appall", "confound", and "amaze", all refer to the great power of language to penetrate the reason and the conscience.

It is important that all of this is to be accomplished through the theatre acting as a moral medium. It is at this point in the play that word becomes translated into deed, and acting and action come together into a word-sword conjunction. Hamlet finally realizes with certainty that his weapon is language, and that his vehicle must be the theatre. We note that language and the theatre can be both seen and heard, and that in the simultaneous engagement of both faculties in the experience of theatre, the one informs the other, and although dis-equilibrium may result for a time, nevertheless there is also the possibility of synthesis to be achieved through reason.

In his examination of theatrical methods, Shakespeare juxtaposes two types: the mime of the Dumb-Show seen by eye alone, and the more comprehensive theatre of the Mouse-Trap, which engages both eye and ear. Some productions of Hamlet leave out the Dumb-Show entirely, but this is a mistake because it is important to the plot and is essential to the thematic structure, imagery, and meaning. The role of the theatre is absolutely central to the meaning of the play, and the Mouse-Trap which finally brings revelation and certainty to Hamlet, is structured so that it is precisely in the middle of the play (III.ii).

Norman Holland, in his brief essay "The Dumb-Show Revisited" points out that the Dumb-Show fits into the "metaphorical structure of the play as a whole". He says that by a "symbolic necessity" Claudius cannot react to the "inexplicable" Dumb-Show, because it does not enter his ears. He points out that the word "ear" occurs twenty-five times in Hamlet, more than in any other Shakespearean play. Also he states that in the Mouse-Trap, because drama enters the ear, therefore, "Claudius must see and understand", and what 
Hamlet does, in effect, is to pour "poison into Claudius' ears". ${ }^{15}$ Holland does not, however, note the significance in the relationship between the eye and the ear.

In the dramatic juxtaposition of the eye and ear in the Dumb-Show and Mouse-Trap sequence Shakespeare is not merely making a statement about drama, but also about the dialectics of perception, and about the essential nature and theory of the theatre. Shakespeare would agree with Marshall McLuhan that "the medium is the message".

Hamlet devises the play so that he can "pique the conscience" and know for certain the guilt of the King. He draws our eyes to the King just before the play begins, so that we note that the King is totally unaffected by the Dumb-Show, which Hamlet has already judged to be "inexplicable" (III.ii.12). In this way, Shakespeare demonstrates that the play which appeals to the eye alone is totally ineffectual. In the Mouse-Trap however, the King is forced to both see and hear the dramatization of his guilty deed, and is trapped by its "argument". He confirms this when he says to Hamlet, "have you heard the argument?" (III.ii.232) (my emphasis). To this Hamlet replies, "they do but jest, poison in jest" (III.ii.232-34). This is a very curious pun on the 'ingesting' of poison, a major theme and image in the play, which is then portrayed in the next part of the play. In this way Hamlet, acting as "chorus", lays the "poison" bait for the King. It is after seeing and hearing or 'ingesting' the play that the King appears to repent, although not sufficiently, because his lust for power is stronger than his faith. ${ }^{16}$

It is important to this argument that the King, in the prayer scene, gives the appearance of repenting. In a sense, this is another Dumb-Show and this time Hamlet is the victim. Hamlet merely sees Claudius praying but cannot hear him, and so does not kill him although he now knows he is guilty. If Hamlet could also hear Claudius, he would know that he is not praying, and would then be able to act. The King speculates on prayer, but does not actually pray. He says, "Pray can I not,/though inclination be as sharp as will". He then rises and says "My words fly up, my thoughts remain below:/ Words without thoughts never to heaven go" (III.iii.36-98). This scene demonstrates again the importance of perceiving with both faculties in the attainment of truth. ${ }^{17}$

The scene of the killing of Polonius follows immediately after the prayer scene. In the dramatic juxtaposition of the two scenes we see that in the prayer scene Hamlet does not kill Claudius because he sees but cannot hear, and then he does kill Polonius because he hears but cannot see. We note the Queen's description of the event: 
[Hamlet] Behind the arras hearing something stir

Whips out his rapier, cries, "A rat, a rat!"

And in this brainish apprehension kills

The unseen good old man (IV.i.9-12)(my emphasis).

Thus Hamlet becomes a victim of his own poor judgement based on that which "seems", which is an erroneous assessment of the sense data available to him.

Ironically, Polonius is killed in the act of his favourite pastime, eavesdropping. His method of gaining knowledge is concentrated almost exclusively on hearing, such as hearsay and rumour, which he chooses to view as certainty, and is killed because of being "too busy" in the very act. He is hidden behind the arras in order to "o'erhear" and is, therefore, unable to see the danger. Similarly, Hamlet hears him but cannot see him and, therefore, acts rashly on the basis of hearing alone, without benefit of the tempering faculty of eyesight, which would have stayed his hand. In a double irony, Polonius is killed by someone who also is relying on hearing to the exclusion of sight, and so, in a sense, he is killed by his own "defect", and "hoist with his own petar" (III.iv.33,207).

When Hamlet kills Polonius, we know by the inevitable law of tragedy that his tragic fate has been sealed. Although Hamlet acts rashly and is guilty of the murder, he feels that a kind of justice has been done. Hamlet says:

I do repent; but heaven hath pleas'd it so to punish me with this, and this with me,

that I must be their scourge and minister (III.iv.173).

Hamlet knows that the scourge of God must also suffer the evil it performs (III.iv.175f). There is a strong sense of mission in this speech, and Hamlet goes on to become the tragic hero of a general purgation and sacrifice.

It is also appropriate that Hamlet should become the instrument of purgation since he was born into the very centre of the conflict - on the very day that his father killed Fortinbras's father (V.i.144). This is the day that the cycle of death and revenge began and, therefore, appropriately, also the day on which the grave-digger came to his job (V.i.142-4). This pivotal fact, placed in the mouth of one of the play's most minor characters, illustrates how closely written is the play, and how even the minor details contain major significance. The fact of Hamlet's unfortunate birthday contains the very key to his fate. The sins of the fathers pass inevitably to the next generation and the new Hamlet, the scholar, must now attempt to find a new and moral course to expiation in keeping with Christian law. 
The killing of Polonius also demonstrates that the Revenge Code is an inappropriate solution, since rashness and danger enter also. Hamlet kills Polonius impulsively thinking it is Claudius, so as not to miss a second opportunity for revenge. He says "I took thee for thy better" (III.iv.32). It is only when Hamlet develops the word-sword method of action that he demonstrates purpose and direction.

The effectiveness of the word-sword is evident when Hamlet confronts his mother with the evidence of the murder. He says, "I will speak daggers to her but use none" (III.ii.396)(my emphasis). We are made aware of the Queen's perceptual limitations when she is unaffected by the Mouse-Trap and can neither see nor hear the ghost (III.iv.113-7). It is only after Hamlet forces his mother to see and to hear that she repents. He forces her to "look" and repeats the word "eye" five times. Hamlet points out to her that of the five senses, she has only appetite, which feeds and gorges on sexual pleasures, and that she is totally lacking in the other four senses and in reason. He says:

Could you on this fair mountain leave to feed,

And batten on this moor? Ha, have you eyes?

Eyes without feeling, feeling without sight,

Ears without hands or eyes, smelling sans all. ...

And reason panders will (IIl.iv.66,7; 78,9; 88).

After this scene, the Queen is forced to see her "shame" and it is then that she admits that Hamlet has turned her "eyes into [her] very soul" (III.iv.53-95). A few lines later, she also acknowledges the faculty of hearing and says, "These words like daggers enter my ears", which paraphrases Hamlet's intention toward her (III.ii.396). The Queen has followed the rational process in which the externally induced emotion of shame achieved through the eye, is internalized into guilt through the ear and reason.

The effectiveness of the word-sword method of action is thus confirmed. After this scene, the Queen is forced to both see and hear and so her reason is now stimulated. The suggestion is made that through this process of awakening of the conscience, Hamlet is able to bring her to "confess herself to heaven" and to repentance (III.iv.149). It is important to the Queen's characterization as a figure of appetite that she should die by ingesting the wine. She also dies because of her natural "defect".

The eye and ear are also important in the scenes with Ophelia, and there is an interesting juxtaposition of the two women in the play. A contrast is set up 
between the total sensuality of Gertrude and the total lack of sensuality of Ophelia. Unlike Gertrude who is poisoned through the mouth, Ophelia is poisoned through the ears by 'ingesting' her brother's and father's dangerous advice which instills fear of her own and of Hamlet's sensuality (I.iii.1-51). In Laertes' speech to her, there are many sensual images of nature, "blood", "moon", "spring", and "dew", but they are all sullied by images of "soil", "besmirching", "danger", "canker", "calumnious strokes", "unmast'red importunity", and "contagious blastments" (I.iii.5-52). We are reminded of Hamlet's sage remarks to Rosencrantz and Guildenstern, "there is nothing either good or bad, but thinking makes it so" (II.ii.249-50). In his speech to Ophelia, Laertes repeats the word "fear" five times. Four times he tells her to fear Hamlet, and once he says, "fear me not" (I.iii.16,33,43,51). Clearly the emphasis is on fear of the body, and Ophelia hears the "good lesson" and accepts it as the "watchman to [her] heart" (I.iii.46). Her capacity to love is thereby totally constrained.

Ophelia's father, Polonius also warns her about Hamlet's affections, but in his speech the emphasis is placed on fear of Hamlet's persuasive capabilities in language, and she is told not to believe his "promises", "vows", "tenders", "unholy suits", or "pious bonds", and finally not to "give words or talk", with Hamlet again (I.iii.134). This also she obeys, and so becomes truncated by Laertes in the body, and by Polonius in the mind. She describes her rational deficiency in her statement to her father, "I do not know ... what I should think" (I.iii.104), and also to Hamlet, "I think nothing, my Lord" (III.ii.117). It is significant that Ophelia's madness takes the curious form of deranged hearing and language, which is precisely the means by which her mind was poisoned against Hamlet (IV.v.1-8).

Hamlet puts on his own private Dumb-Show for Ophelia in which the eyes are featured, and thereby attempts to stimulate Ophelia's eyes into response in order to counteract the poisonous advice that she has received through the ear, but this also is ineffectual. In this scene, Hamlet does not speak or engage her ear in any way, but attempts to force her eyes to engage in an exchange with his own. He holds her firmly, stares long and hard into her eyes, as if to draw them out, and continues staring "to the last" as he retreats in defeat (II.i.84-97). This scene foreshadows the Dumb-Show of Act III, and demonstrates that the Dumb-Show is an ineffective form of communication. Poor Ophelia finds both Dumb-Shows "inexplicable" (III.ii.143). The scene also shows that language is vital to the understanding, however, language is not possible between Hamlet and Ophelia because her father and brother have preempted it. 
Ophelia totally denies her sensuality in denying Hamlet's love, and so he commands her five times, once for each sense, "get thee to a nunnery" (III.i.120-49). After the "nunnery" scene in which Hamlet uses language in the word-sword sense, Ophelia does finally see, and this also is repeated five times (III.i.157-62). In this speech, Ophelia mentions all of the senses except touch (feeling). As her name "O-phelia" implies, she has no love or feeling, and dies with her "chaste treasure" intact - she is drowned and swept away by her "one defect", her own purity. While the full-blooded Gertrude dies by wine, Ophelia dies by water.

There is a strong fundamental theme throughout the play that by a universal law of justice, the evil act brings its own retribution (I.iv.31). In the rash act, Hamlet is an "enginer" who is "Hoist with his own petar" (III.iv.207); Laertes says, "As the Woodcock ... I am justly killed with mine own treachery" (V.ii.307); and Claudius, is killed by "a poison temper'd by himself (V.ii.328).

It would appear that the "stamp of one defect", or the "mole of nature" is an insurmountable human problem - a kind of original sin (I.iv.24-38). In spite of the fatalism suggested by the inherent "mole", there is also the suggestion counter to fatalism and determinism, that man has the capability within himself to change his character. An illustration of this is Hamlet's advice to his mother, in which he says, $\mathrm{O}$, throw away the worser part of it. .../Assume a virtue. .../ For use almost can change the stamp of nature" (III.iv.157-68). There is also the suggestion that these defects could have been tempered by the use of reason, and a more thorough attention to all of the sense data available to the individual at the time.

Hamlet undergoes a development of character in time as the play progresses, and Rabkin notes that Shakespeare, in his mature work, "portrays extended time, because he sees character as changing". ${ }^{18}$ In some of the other plays, Shakespeare shows development taking place because of love. However, in Hamlet the development occurs because of reason and is, therefore, nearer the modern ideas of existential freedom and responsibility.

The character of Fortinbras, like Hamlet, undergoes change in time as the play progresses. At the beginning he is "of unimproved mettle hot and full", a vengeful warmonger, and symbolizes the old Revenge Code (I.i.95-105). Some development is shown in the fact that he does submit to embassies, negotiations and compromise, and embraces his fortune with sorrow (V.ii.388). Also, he wishes to "see", and is moved by the "sight" of the "dismal" carnage. He shows a new willingness to hear and to learn when he says, "let us haste to hear it" (V.ii.386-88) (my emphasis). He then collabo- 
rates with Horatio in theatre - in dramatizing the event so that it will be "presently perform'd/ ... while men's minds are wild" and thus prevent further bloodshed (V.ii.393-95). The scene suggests that this new emphasis on both eye and ear, and exposure to language and reason, will result in a more sober and moderate Fortinbras as he becomes ruler.

The ending of the play in which Fortinbras is 'elected' to the throne by Hamlet shows that justice has been done and that the revenge cycle can now cease. Fortinbras says: "I have some rights of memory in this kingdom (V.ii.389-90). Therefore, the ending of the play, which appears to be totally pessimistic, and even resembles the modern theatre of the absurd, nevertheless has some elements of resolution and hope for the future. A universal justice appears to be at work, but Shakespeare the realist, also shows that the 'defects' are inherent in the next generation.

In summary, Hamlet, a play about uncertainty, doubt and irony, reflects the intellectual and moral conflict as the Elizabethan age struggles with the abolition of the Revenge Code. The new generation's awareness that "the time is out of joint", and desire "to set it right" is analogous with the age's sense of transition and search for a new way (I.v.188-89). With profound irony, the play demonstrates that the ghost of the past tradition cannot be easily extinguished, but lives on to generate a dialogue between past and present, which finally requires violence and destruction before resolution can be achieved.

The profusion of eye and ear imagery in the play reflects Shakespeare's philosophy about the dialectical relationship between the eye and the ear and the reason. He shows that the exclusion of one or the other results in a truncation of the intellect and thus, in unwholesome judgement and action.

Shakespeare's allusions to the theatre in Hamlet demonstrate his concern for its wellbeing and freedom of expression. The theatre's very existence is being threatened at the time of writing, and is one of Shakespeare's and of Hamlet's concerns in the play (II.ii.329-62fn; p.1136). Shakespeare is concerned not merely for his livelihood, art, and the means of transmitting his ideas, but he also defends the theatre as a very effective moral medium which stimulates both eye and ear into a dialectic within the reason and conscience.

Shakespeare's directive to Horatio the orator, makes it plain that the moral is conveyed to "th' yet unknowing world" by the poet through language, and that his most effective medium is the theatre. Just as Shakespeare intended, the experience of this play mirrors its intent. We as the audience, are compelled to participate in the process as we struggle along with Hamlet in the search for truth and meaning. Hamlet defends the importance of the 
theatre's role in history as an "abstract" medium and he invokes the eye and the ear as he says:

Will you see the players well bestow'd?

Do you hear, let them be well us'd, for they are

the abstract and brief chronicles of the time.

(II.ii.522-25) (my emphasis).

\section{Notes}

1. Northrop Frye, Northrop Frye on Shakespeare, ed. Robert Sandler (Markham, Ontario: Fitzhenry \& Whiteside, 1986) 89.

2. It is significant that it is at Wittenberg that Hamlet was being educated, since that is where Martin Luther launched the Reformation in 1517, less than 100 years before Shakespeare wrote Hamlet. These were turbulent years of transition in England, with Henry VIII, Sir Thomas More, Mary Queen of Scots, the reigning Elizabeth I, and James, an ardent Protestant who would soon become King of England.

3. Harry Levin,"The Question of Hamlet," Shakespearean Criticism Vol. I, ed. L.L. Harris (Detroit: Book Tower, 1985) 227-30.

4. Anthony Brennan, Shakespeare's Dramatic Structures (London: Routledge \& Kegan Paul, 1986) 130.

5. William Shakespeare. ed. G.B. Evans, The Riverside Shakespeare (Boston: Houghton Mifflin, 1974). All further parenthetical references are to this edition.

6. Levin 227-30. Levin speculates on this question: "Whether Hamlet was being led astray to eternal damnation or being enjoined to perform a sacred duty would thus be contingent on theological questions which were moot".

7. Margot Heinemann, "How Brecht Read Shakespeare", Political Shakespeare, ed. Jonathan Dollimore, (London: Cornell UP, 1985) 217.

8. Fredson Bowers, Elizabethan Revenge Tragedy (Princeton: Princeton University Press, 1966) 10, 11. Also see Chapter One in general.

9. Alfred Harbage, Shakespeare and the Rival Traditions (New York: Columbia University Press, 1952) 171-72. He says: "Any who take personal vengeance become murderers. Speculation over the reason for Hamlet's hesitation to slay Claudius has been singularly unconcerned with Shakespeare's hesitation to convert his hero into a villain. His audience would have looked askance at any slaying not committed in combat and heat of battle."

10. Wilson, What Happens in Hamlet, (London: Cambridge University Press, 1967), 84.

11. Allan Bloom, Shakespeare's Politics (New York: Basic Books, 1964), 103. Also the Robinson text (p.53) notes that Julius Caesar (1599) was still fresh in Shakespeare's mind when he wrote Hamlet (1600-01).

12. Norman Holland, "The Dumb-Show Revisited". Notes and Queries (May, 1958): 191.

13. Brennan, 130-1.

14. Norman Rabkin, Shakespeare and the Common Understanding (New York: Free Press, 1967), 250-1. Rabkin argues that the mature Shakespeare, in plays such as Hamlet, 
King Lear, and Macbeth, portrays extended time and shows his characters changing over the course of their plays. He says that in Shakespeare, "indeed, villainy consists in a character's vice-like inability to change".

15. Holland, 191.

16. Bowers, 9. This is also evident in the final scene in which Claudius' love of power is stronger than his love of the Queen, so that even though he asks her not to drink the poison, nevertheless, he does not physically prevent her from doing so. Bowers states that by Elizabethan law, "Claudius in Hamlet is guilty of first-degree murder, and not of manslaughter when Gertrude dies of the poison he has intended for Hamlet".

17. The prayer scene also serves to demonstrate Hamlet's deep commitment to the Christian faith, unlike Laertes, who would kill "i' th' church" (IV, vii, 127).

18. Rabkin, 250-1. 